\title{
FENNTARTHATÓ AGRÁRGAZDÁLKODÁS A KLÍMAVÁLTOZÁS TÜKRÉBEN
}

\section{SUSTAINABLE AGRICULTURAL MANAGEMENT IN VIEW OF CLIMATE CHANGE}

\author{
Nagy János ${ }^{1}$, Nagy Orsolya ${ }^{2}$ \\ 'az MTA doktora, nagyjanos@agr.unideb.hu \\ 2PhD, orsolyanagy.dr@gmail.com
}

Debreceni Egyetem Mezőgazdaság-, Élelmiszertudományi és Környezetgazdálkodási Kar Klímaváltozás Kutatócsoport, Kerpely Kálmán Doktori lskola

\begin{abstract}
ÖSSZEFOGLALÁS
A feltételezett éghajlatváltozás (lehetséges) hatásai Magyarországon a növénytermesztésre kedvezőtlen hatást gyakorolnak, elsősorban a vízellátottság jelentős csökkenése formájában. A hőmérséklet emelkedő tendenciája súlyosbítja az aszályos helyzetet. A szűkös természetes vízellátás és a gyakori vízkárok (vízhiány, belvíz) bekövetkezése szükségessé teszi a mezőgazdasági vízgazdálkodás infrastrukturális hátterének fejlesztését és az öntözött területek növelését. A klimatikus eredetű károk a precíziós termesztéstechnológiák fejlesztését lassíthatják, ezáltal a magyar mezőgazdaság versenyképességének megőrzésére is kedvezőtlenek. Ökonómiai szempontból a jó minőségű, nagy termések eléréséhez szükséges energiaigény (biológiai, kémiai, fosszilis, elektromos stb.) folyamatos kielégítése nagy kockázati forrást képez, mivel a kedvező évjáratok aránya kicsi. Ennek figyelembevételével válik szükségessé a jövőben egy olyan innovatív termesztéstechnológiai rendszer fejlesztése, amely a talaj-növény kölcsönhatások sajátosságaihoz és a megváltozott - feltételezett - klimatikus környezethez egyaránt illeszkedve minimalizálja a szélsőséges aszálykárokat, biztosítva ezzel a fenntarthatóságot.
\end{abstract}

\section{ABSTRACT}

The (possible) impacts of the assumed climate change are inauspicious from the aspect of crop production in Hungary, primarily concerning the significant reduction of water supply. There is a tendency of rising temperatures and it makes the effects of drought even more severe. The low level of natural water supply and the frequent water-related damages (water shortage, groundwater inundation) necessitate the development of the infrastructural background of agricultural water management and the increase of irrigated areas. Damages of climatic origin may slow down the development of precision production technologies; therefore, they are also unfavourable in maintaining the competitiveness of the Hungarian agriculture. From the economic aspect, the constant provision of (biological, chemical, fossil, electric, etc.) energy needed for achieving high yields of great quality represents a severe risk source since the proportion of favourable crop years is low. As a conclusion, it is important to develop an innovative production 
technological system which minimises extreme drought damages and provides sustainability while adapting to the peculiarities of plant-soil interactions and the changed - assumed - climatic environment.

Kulcsszavak: fenntartható fejlődés, klímaváltozás, precíziós növénytermesztés

Keywords: sustainable development, climate change, precision crop production

\section{BEVEZETÉS}

A klímaváltozás, illetve hatásainak elemzése, napjaink egyik legnagyobb tudományos és társadalmi érdeklődést, vitát kiváltó kutatási témája. Vitathatatlan, hogy az emberiség jövőjét jelentősen befolyásolja a klímaváltozásban rejlő veszélyek felismerése és feldolgozása, illetve értékelése. Ezért a klímaváltozás kezelésére, visszaszorítására vonatkozó erőfeszítések megtervezése, majd megtétele mellett megkerülhetetlenül mérlegelendő, a számos kockázaton és áldozaton túl, a rövid távú gazdasági érdekek sérülékenysége is. A természettudományok, az agrártudomány, illetve a müszaki tudományok egyaránt szinte versenyt futnak az idővel és egymással, ötleteket keresve a hétköznapi, egyszerủ megoldásoktól, egészen a korszakalkotó koncepciókig. A klímaváltozással érintett tudományterületek közül az egyik legérzékenyebb a mezőgazdaság. Ráadásul, a fenntartható mezőgazdaságról és a vidékfejlesztésről regionális léptékben kell gondolkodni, hiszen függnek a földrajzi elhelyezkedéstől és az éghajlati adottságoktól, mégis, a nyújtott szolgáltatással messze túljuthatnak a régió fizikai határain. Ráadásul nincs konszenzus a világ tudósai között arról, hogy az éghajlati viszonyok átalakulásáért, a biológiai sokféleség hanyatlásáért, a termőtalaj pusztulásáért, a szennyezés és kiszáradás következtében világszerte fenyegető ivóvízhiányért döntően az emberek tehetőek-e felelőssé, pontosabban azok bizonyos (kapitalista) magatartásai (Pretty, 2008).

\section{A KIOTÓI JEGYZŐKÖNYVTŐL A PÁRIZSI „KLIMACSÚCSIG”, VAHAVA}

A különböző tudományok képviselöi között is elismert tény, hogy a Föld klímája változik. Ám a változást kiváltó okok és azok hatásának megítélésében a vélemények igen eltérőek. A klímaváltozás folyamatának visszafordítására nincs mód, de hatásainak mérséklésére továbbra is vannak lehetőségek. Az Európai Unió Kiotói Jegyzőkönyvben tett ígérete alapozta meg az unió közös éghajlat-politikáját, amelynek első számú célkitüzése az üvegházhatású gázok kibocsátásának csökkentése volt (Fodor et al., 2006). A célkitüzések elérésének stratégiai 
programja a 2000-ben indított Európai Éghajlatváltozás Program, amely kiterjedt ipari, közlekedési, mezőgazdasági, energiafelhasználási és energiaellátási kérdésekre is. Majd az unió tagállamai azt a politikai célt tüzték ki 2020-ra, hogy az 1990-esnél 20 százalékkal alacsonyabbra szorítsák le az üvegházhatást okozó gázok kibocsátását. Ez egy időre szimplán politikai akarat volt, amit a 2015-ös párizsi klimakonferenciáig nem követett kötelező elöírás, szemben a másik két, ugyancsak 20 százalékos célkitüzéssel, amelyeket jogszabály ír elő. Ezek szerint 20 százalékkal kell növelni a megújuló energia felhasználásának arányát, valamint - a hatékonyság javításával - 20 százalékkal kell mérsékelni a teljes energiafelhasználást az unión belül. 2050-re már a szén-dioxid-kibocsátás 80 százalékos mérséklését irányozták elő; ennek eléréséhez viszont az energiaszektor teljes megújulására, energetikai-technológiai revolúciójára van szükség.

Az éghajlatváltozásról a legátfogóbb globális képet az IPCC- (Intergovernmental Panel on Climate Change) jelentések adják. A jelentések tartalmára alapozva több száz kutatómunka készült, valamint az eredmények objektívebben értékelhetővé váltak. A hazai kutatások előbb a VAHAVA- (VÁltozás, HAtás, VÁlaszadás), majd a KLIMAKKT- (Felkészülés a klímaváltozásra Környezetkockázat-társadalom) program keretében számos területen végeztek elemzéseket az éghajlatváltozás magyarországi hatásaira vonatkozóan (Szász, 2005a; Láng et al., 2007; Berényi, 2011). Következtetésképp egy gyakran feltett közös kérdés rögzíthető a klímaváltozással kapcsolatban: az vajon milyen hatást gyakorol a mezőgazdaságra, tágabb értelemben az élelmiszer-ellátásra (Babinszky et al., 2011)? A válaszhoz elengedhetetlen a klimatológusok által elkészített éghajlati forgatókönyvek pontos helyi lebontása és értékelése, valamint azok összekötése a helyi regionális termelési tapasztalatokkal. A rendelkezésre álló biológiai, biometriai és meteorológiai adatok statisztikai módszerekkel történő vizsgálata pedig összefüggések feltárására ad lehetőséget.

\section{A MEZŐGAZDASÁGI KLÍMAKUTATÁSOK EREDMÉNYEI}

A mezőgazdaságban végzett klímaváltozás-kutatások eredményeinek elemzései alapján, Harnos Zsolt és Csete László (2008) egymással összhangban azt állítják, hogy a hőmérséklet-emelkedés miatt tolódtak el az agro-ökológiai zónák. Ezenfelül hosszabbak lettek a tenyészidők, és tovább növekedett a fotoszintézis, ugyanakkor a legtöbb fejlődő országban csökkent a cereáliák termőképessége. A kilátásba helyezett tervekben pedig a legnagyobb kárt, a hőmérséklet ingadozásán túlmenően, a szélsőséges esetek gyakoriságának növekedése okozza. Várallyay György és Láng István (2009) közösen hívták fel a figyelmet a talajra mint hatalmas potenciális természetes víztározóra, amely képes a klímaváltozás hatásait tompítani, mérsékelni, de éppúgy képes a szélsőséges helyzetek felnagyítására, 
súlyosbítására is. Emiatt nőtt meg a talaj vízgazdálkodásának, anyagforgalmának, illetve ezek szabályozásának jelentősége.

Varga-Haszonits Zoltán (1997) ezért is javasol megkülönböztetést a lehetséges és a tényleges vegetációs periódusok között. A napi középhőmérséklet emelkedésének az lesz a következménye, hogy a lehetséges vegetációs periódus hossza kitolódik. Ugyanakkor a magasabb hőmérséklet következtében a növények életciklusa a felgyorsult növekedés miatt lerövidül, és ezért a tényleges vegetációs periódus hossza csökken. Ugyanakkor a magas hömérséklet a transzspirációt is fokozza, ami hozzásegít a talaj gyorsabb kiszáradásához, és ez újabb abiotikus stressz eredője lehet. A felmelegedés és az azzal járó szárazodás pedig érzékenyen érintik az egyes tápelemek hasznosulásának mértékét (is) (Nagy, 2005). Tartós aszályban a mütrágya hasznosulása jelentősen csökken. Ám a túlságosan nagy mennyiségü csapadék sem kedvezö. Ilyen helyzetekben értékelődik fel a vetésforgó és a zöldtrágyázás szerepe. Az éghajlat nagyfokú változékonysága a termelés egyik legnagyobb hatásfokú kockázati tényezője, amellyel folyamatosan számolni kell a precíziós mezőgazdaságban. A huszadik század elején a meteorológia nagy fejlődésnek indult (Mészáros, 2014), és napjainkra, különböző statisztikai eljárások segítségével, az egyes jelenségek módosulásai szignifikánsan bizonyíthatóakká váltak. A változás okát többen az üvegházhatású gázok felhalmozódásával magyarázzák, aminek van fizikai alapja, azonban ez nem tekinthető olyan kizárólagos effektusnak, amely az éghajlatnak olyan mértékủ változását okozná, mint amit a közeljövőre valószínüsítenek. Az üvegházhatású gázok mennyisége igen nagy mértékben növekedett, ezek közül kiemelendő a szén-dioxid, s logikusan, a nagyfokú emelkedés a légkör üvegházhatásának növekedését eredményezte. A felmelegedés folyamatát elemezve, az utóbbi száz évre vonatkozóan, azt $+0,6-+0,8{ }^{\circ} \mathrm{C}$-ban állapították meg, amely már képes a kultúrnövények termesztési határát a sarkok felé eltolni. Bár az emelkedés nem folytonos, azonban e hosszú időre vonatkoztatott tendencia kétségtelenül igazolható.

\section{A KLIIMAVÁLTOZÁS ÉS AZ ASZÁLY MAGYARORSZÁGON}

A nemzetközileg elfogadott felmelegedés mértéke Magyarországon is bizonyítható. Igaz, a magasabb átlaghőmérséklet önmagában nem veszélyezteti alapvetően a növénytermesztést, mégis több problémát okoz a mezőgazdaság számára az emelkedéssel egyidejüleg fokozódó hőmérsékleti szélsőségek gyakorisága. Eklatáns példa a téli időszakok és az átmeneti évszakok rövidülése. A hőmérséklet-emelkedés mellett másik kedvezőtlen hatása a csapadék nagyfokú csökkenése. Hazánk a mérsékelt égöv kontinentális klímahatárán helyezkedik el, ahol a nyári aszályos helyzetek gyakorisága jelentős méreteket öltött. A csapadék Magyarországon, föként az ország középső és déli területein, évi átlagban 
mintegy 50 mm-t csökkent száz év alatt, ami a növények vízigényéhez mérten rendkívül nagy. Emellett egyre inkább hosszabbodtak a csapadék nélküli idöszakok, és gyakoribbá váltak az aszályos évszakok (Szász, 1988; 2005b). A feltételezett éghajlatváltozás ezen megnyilvánulása rendkívül hátrányosan hat föként a vízigényesebb kultúrák termesztésére.

Az aszály mint legsúlyosabb vízhiány gazdasági katasztrófát jelent a növénytermesztésben. A csapadék időbeni és területi változékonysága kis országunk területén is különböző, így az aszályhajlam is változó. A kultúrnövények vízellátását elsősorban az atmoszferikus csapadék biztosítja, ezen csapadék a termést meghatározó egyik legfontosabb tényező. A hazánk területére lehulló csapadék mennyisége általában nem elégíti ki a növények igényét, csupán azok vízigényének közepes mértékủ kielégítését biztosítja (Németh, 1996). Ezért a szántóföldi növénytermelésben kulcskérdés a csapadék befogadása és megőrzése. Ennek érdekében kiemelt jelentőségűvé válik a tarlóhántás, a tarlóápolás és - ahol lehetséges - a talajtakarás alkalmazása. A szárazságot - esetenként a nagy mennyiségü csapadékot - figyelembe vevő talajmüvelés (például október-november hónapokban a téli csapadékmennyiséget jól befogadó alap-talajmüvelés elvégzése) kulcsfontosságú. Meghatározó a termőhelyi adottságokhoz és a növény igényeihez igazodó termesztéstechnológia, a szárazságot, illetve a szélsőséges hatásokat jobban türő fajták/hibridek fokozottabb termesztésbe vonása, illetve az e célokra történő nemesítés (Nagy, 2008; 2017).

\section{KOCKÁZATOK A NÖVÉNYTERMESZTÉSBEN}

A magyar mezőgazdaság egyik kiemelkedő ágazata, a növénytermesztés ökonómiai kockázatát elsősorban a klimatikus feltételek határozzák meg (Szász, 2013). Az éghajlat-változékonyság felgyorsulását globálisan és regionálisan már a múlt században részletesen kiterjedt müszeres mérések bizonyították. A klimatikus feltételek alakulásának jövőbeni becslésére különböző szcenáriók sztochasztikus és tranziens modelljei szolgálnak. A mezőgazdálkodás klimatikus feltételeinek becslésére azok a szcenáriók alkalmasak, amelyek elsősorban a növényi igények idő szerinti változásának irányait fejezik ki (például: hőmérséklet, annak szélsőségei, csapadék stb.). A Kárpát-medencében az elmúlt száz év alatt $0,6{ }^{\circ} \mathrm{C}$-os átlagos évi középhőmérséklet-emelkedés következett be a szélsőségek fokozódásával.

A növénytermesztés szempontjából Magyarország természetes csapadékellátottsága egykoron is csak mérsékelt volt, amely az elmúlt száz év alatt jelentősen csökkent, a csökkenés mértéke: $20-70$ mm év/10 év. A csökkenés tendenciája mellett igen nagy az évi összegek ingadozása (min.: $350 \mathrm{~mm} / \mathrm{e} v$, max.: $1100 \mathrm{~mm} / \mathrm{e} v$ ). A mezőgazdaság fenntartható fejlődésének biztosítása megköveteli az éghajlat 
változékonysága elleni védekezés stratégiájának kidolgozását, méghozzá az ahhoz alkalmazkodó precíziós technológiák formájában. A munka legfontosabb előfeltétele a változékonyság és hatásainak, okainak, várható gyakoriságának becslése. Ehhez kellő alapot jelent a jelenlegi és a valószínüsíthető tendenciák megismerése. A jelenlegi és újabb szcenáriók átskálázásai információt nyújtanak a mezőgazdaság, azon belül pedig a növénytermesztés jövőbeli klimatikus feltételeiről. Nem lehet eltekinteni attól, hogy az intenzív növénytermesztés elterjedésével a növények vízigénye is növekedett, egyrészt a genetikai tulajdonságok megváltozása folytán, másrészt a területegységre eső egyedszámok gyarapodása következtében. Ilyen körülmények között a víz hiánya jelentős terméscsökkenést vált ki.

A változó éghajlati feltételekhez történő alkalmazkodás egyik - egyben legfontosabb - lehetősége a klimatikus adottságokhoz viszonylag jól illeszkedő tulajdonságokkal rendelkező fajták, genotípusok termőképesség és igények szerinti elemzése. Hangsúlyoznunk kell, hogy Magyarországon - föként a kedvező talajtermékenységü termőtájakon - a csapadékellátottság és a gyakori tartós aszály gátolja a kívánatos termésszint stabil elérését. Vizsgálataink szerint, a javuló biológiai alapok biztosításával a termések ingadozása egyre nagyobb, melynek elsődleges oka a vízhiány. Kedvező vízforgalmú évjáratokban a gabonafélék termésszintje kb. 10 t/ha, míg aszályos évjáratban a betakarítható termés 2-3 t/ha. A nagy különbség mérsékelhetỏ a minimális termések szintjének emelésével, ahhoz pedig megfelelő talajművelés, víz- és tápanyagellátás biztosítása szükséges. Az aszály elleni védekezésben a legfontosabb a mezőgazdasági vízgazdálkodás infrastrukturális hátterének fokozott korszerüsítése. Hazánk talajainak vízgazdálkodási tulajdonságai nagyobb részt kedvező feltételek között alakulnak, így vízraktározó és vízvezető képességük is kedvező, de a kötöttebb talajú területeken nem ritka a belvíz okozta kártétel.

\section{PRECÍZIÓS NÖVÉNYTERMESZTÉS}

Magyarország abban a szerencsés helyzetben van, hogy rendelkezésére állnak a megfelelő ipari és mezőgazdasági kapacitások, bár szem előtt kell tartani a potenciális feszültség kialakulását, az élelmiszer és az ipari célú mezőgazdasági termelés között. A biztonságos takarmánynövény- és élelmiszer-alapanyag elöállításhoz pedig a szántóföldi precíziós termesztéstechnológiák fejlesztése szükséges. A növénytermesztésben legkorszerübb precíziós módszerekkel termesztett növények mennyiségi és minőségi paramétereinek mérése lehetővé teszi a környezetterhelés minimálisra csökkentését, és garantálja annak fenntarthatóságát, valamint az ökológiai potenciál kihasználhatóságát. Ezzel lehet megalapozni a táblán belüli kezelések optimalizálását. A környezetterhelés csökkenthető pon- 
tos tápanyag-visszapótlás és minimális mennyiségben kijuttatott növényvédőszer-adagolással. A precíziós növénytermesztés megvalósítja a termőhely térbeli heterogenitásához illeszkedö, gazdaságos és fenntartható gyakorlati növénytermesztést. Arra kell törekedni, hogy toleráns fajták, hibridek, genotípusok kerüljenek a köztermesztésbe, ezzel védekezve a kedvezőtlen klimatikus hatásokkal szemben. A klímaváltozás, amely egy meghatározott trend körüli nagy szórásban nyilvánul meg, fokozódó szélsőségeket, például kedvezőtlenül magas vagy alacsony hőmérsékletet, továbbá tartós, kedvezőtlenül nagy mennyiségü vagy kevés csapadékot és azokkal járó elemi károkat képes okozni. Ilyen körülmények esetén a jövőbeli eredményes, fenntartható termeléshez, a kedvező biológiai alapok és a precíziós termesztéstechnológiai rendszer összehangolása szükséges. A preventív korrekciós technológia kidolgozása, széles körü integrált információs rendszer fejlesztését követeli meg, amely területen Magyarországnak még sok a teendője.

$\mathrm{Az}$ eddigi termesztési tapasztalatok alapján ismert, hogy a klimatikus kontinentalitás fokozódásával az egyes meteorológiai elemek szélsőségei - egy bizonyos határig - növekednek, amelyek a termések szóródásának távolságában és mennyiségében nyilvánulnak meg. Sok évtizedes hazai és külföldi szabadföldi tartamkísérletek, valamint termesztési tapasztalatok azt bizonyítják, hogy a termesztés színvonalának növekedésével fokozódnak az időjárási hatások, tehát a klíma hatásaival szembeni érzékenység növekedése az ökológiai feltételektöl függ (ún. tájhatás). Azokon a területeken, ahol a klimatikus kontinentalitás erőteljes, ott a termések mennyiségének ingadozása jelenti a termesztési kockázatot. Továbbá az éghajlati szélsőségek gyakoriságának fokozódása, valamint a kedvezőtlen hatások ellensúlyozása jelentős energiafelhasználást igényel. Jó közelítéssel kiszámítható, hogy miként alakul az egységnyi fötermék előállításához szükséges energia (E: MJ/ha) és a termék energiája (P: MJ/tonna, ha) aránya. Kedvezőtlen tapasztalati tény, hogy alacsony termelési szintnél ez a relatív arány viszonylag nagy $(\mathrm{P} / \mathrm{E}>3,5)$, a termésszint emelkedésével az arányszám csökken. Magyarországon az elmúlt évtizedekben a gabonanemúekre számított arány átlagértéke: $2,3 \%$. Ha feltételezzük az éghajlat változékonyságának növekedését, úgy az energiafelhasználás fajlagos értéke nő, viszont ezzel együtt a produkció és a felhasznált energia aránya kedvezőtlenül csökken.

A precíziós kukoricatermesztés fejlesztésében is jól hasznosíthatók a Debreceni Egyetem Európában egyedülálló, szántóföldi kukorica tartamkísérletének eredményei, amelyek alapján megfelelően számszerüsíthetők a klímaváltozás hatásai. A klimatikus tényezők szélsőséges ingadozását jól mutatja, hogy a harmincnyolc éves kukoricatermesztési periódus alatt, kedvező évjáratokban, 1987 és 1988-ban $1 \mathrm{~mm}$ csapadékra 41, illetve $52 \mathrm{~kg}$, míg a szélsőségesen aszályos évjáratokban mindössze 10 , illetve $12 \mathrm{~kg}$ volt a kukoricatermés hektáronként (1. ábra), 1980-2017 között éves átlagban a tenyészidőszakban lehullott $1 \mathrm{~mm}$ csapadékra $23 \mathrm{~kg} /$ ha termés jutott. 


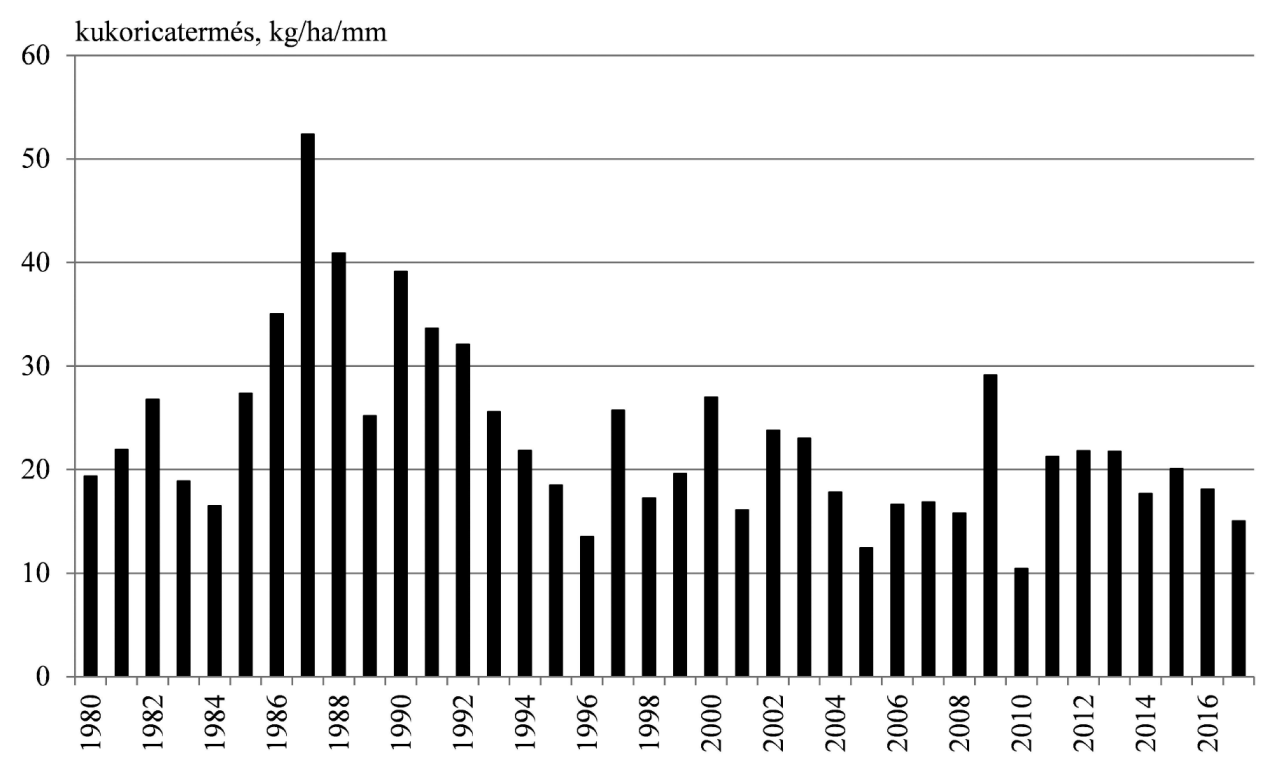

1. ábra. A tenyészidőszakban lehullott $1 \mathrm{~mm}$ csapadékra jutó kukoricatermés

(Debrecen, 1980-2017) (Nagy J., 2017)

Az aszály elleni aktív védekezési eljárások közül ki kell emelni az öntözést. Jelenleg Magyarországon az öntözés mind ökonómiai, mind műszaki szempontból rendkívül nehéz helyzetben van, ennek ellenére szükségesnek tünik e komplex probléma technológiai, valamint ökonómiai felülvizsgálata és a rendelkezésre álló vízkincs gazdaságos hasznosítása.

Az ENSZ Élelmiszer és Mezőgazdasági Szervezete (FAO) szerint megoldás a klímaváltozás hatásainak mérséklésére a klímatudatos mezőgazdaság kialakítása (Corporate-Smart Greenwash, 2014). Ennek elemei: a fenntarthatóan növekvő mezőgazdasági termelékenység, a méltányos mezőgazdasági jövedelem, az élelmiszer-biztonság és fejlesztés, a mezőgazdasági és élelmiszer-biztonsági rendszerek többszintű és rugalmas alkalmazkodóképessége, valamint a mezőgazdaságból származó üvegházhatású gázok emissziójának csökkentése.

\section{KÖSZÖNETNYILVÁNITÁS}

A publikáció elkészítése az EMMI által meghirdetett FIK-program keretében a Debreceni Egyetem 4. tématerületi program, valamint az EFOP-3.6.3-VEKOP-16-2017-00008 és a GINOP-2.2.1-15-2016-00001 azonosító számú projektek támogatásával valósult meg. 


\section{IRODALOM}

Babinszky L. - Dunkel Z. - Tóthi R. et al. (2011): The Impacts of Climate Change on Agricultural Production. Hungarian Agricultural Research: Environmental Management Land Use Biodiversity, 20, 2, 14-20.

Berényi D. (2011): Klímaváltozás, globális felmelegedés, $\mathrm{CO}_{2}$-hatás - kritikus szemmel. Magyar Tudomány, 172, 1, 18-31. http://www.matud.iif.hu/2011/01/03.htm

Corporate-Smart Greenwash (2014): Why We Reject the Global Alliance on Climate-Smart Agriculture. http://www.climatesmartagconcerns.info/rejection-letter.html

Fodor L. - Baranyi T. - Tóth K. (2006): Környezetjog. Debrecen: Licium-Art Könykiadó és Kereskedelmi Kft.

Harnos Zs. - Csete L. (2008): Klímaváltozás: környezet - kockázat - társadalom. Budapest: Szaktudás Kiadó Ház, 9-14.

Láng I. - Csete L. - Jolánkai M. (szerk.) (2007): A globális klímaváltozás: hazai hatások és válaszok. A VAHAVA jelentés. Budapest: Szaktudás Kiadó Ház

Mészáros E. (2014): Meteorológia a XX. század első felében. Tallózás a hazai szakirodalomban. Magyar Tudomány, 175, 6, 679-691. http://www.matud.iif.hu/2014/06/08.htm

Nagy J. (2005): A mezőgazdasági földhasználat, a szántóföldi növénytermelés és a vízgazdálkodás. (,, Agro-21" füzetek 41) 38-46.

Nagy J. (2008): Maize Production. Budapest: Akadémiai Kiadó

Nagy J. (2017): Klímaváltozás és a mütrágyázás hatása a kukorica termésére debreceni tartamkísérletben. Növénytermelés, 66, 3, 11-32.

Németh T. (1996): Talajaink szervesanyag-tartalma és nitrogénforgalma. Budapest: MTA Talajtani és Agrokémiai Kutató Intézete

Pretty J. (2008): Agricultural Sustainability: Concepts, Principles and Evidence. Philosophical Transactions of the Royal Society B, 363, 447-465. http://rstb.royalsocietypublishing.org/content/royptb/363/1491/447.full.pdf

Szász G. (1988): Agrometeorológia. Budapest: Mezőgazdasági Kiadó

Szász G. (2005a): Az éghajlat változékonysága és a szántóföldi növények termésingadozása. (,,Agro-21" füzetek 38) 59-57.

Szász G. (2005b): Termésingadozást kiváltó éghajlati változékonyság a Kárpát-medencében. (,, Agro-21" füzetek 40) 33-69.

Szász G. (2013): Agrometeorological Research and Its Results in Hungary (1870-2010). Időjárás. Quarterly Journal of the Hungarian Meteorological Service, 117, 3, 315-358. https://www.met. hu/downloads.php?fn=/metadmin/newspaper/2013/09/76b9210ad22e54be2d5996bea7fa3790117-3-4-szasz.pdf

Várallyay Gy. - Láng I. (2009): A hazai környezetállapot vizsgálata, különös tekintettel a klímaváltozásra. In: Bertelsmann Stiftung (ed.): Strategies for Combating Right-Wing Extremism in Europe. Gütersloh: Bertelsmann Foundation, 281-302.

Varga-Haszonits Z. (1997): Agrometeorológiai információk és hasznosításuk. In: Szász G. (szerk.): Agrometeorológia. Budapest: Mezőgazdasági Kiadó 